\title{
The Mofetta Tylicz - an example of carbonated water springs in the area of Tylicz (Beskid Sądecki, the Carpathians)
}

\author{
Magdalena Modelska*, Sebastian Buczyński, Marek Błachowicz, Monika Heidemann, Olga Grzęda, Łukasz Karkoszka
}

Magdalena Modelska: University of Wrocław, Institute of Geological Sciences, PI. M. Borna 9, 50-204 Wrocław, POLAND

Sebastian Buczyński: University of Wrocław, Institute of Geological Sciences, PI. M. Borna 9, 50-204 Wrocław, POLAND

Marek Błachowicz: University of Wrocław, Student Science Association of Geologists, Hydrogeology Section, PI. M. Borna 9, 50-204 Wrocław, POLAND

Monika Heidemann: University of Wroctaw, Student Science Association of Geologists, Hydrogeology Section, PI. M. Borna 9, 50-204 Wroctaw, POLAND

Olga Grzęda: University of Wrocław, Student Science Association of Geologists, Hydrogeology Section, PI. M. Borna 9, 50-204 Wrocław, POLAND

Łukasz Karkoszka: University of Wrocław, Student Science Association of Geologists, Hydrogeology Section, PI. M. Borna 9, 50-204 Wrocław, POLAND

Record

Chemical composition and its variability of the Mofetta Tylicz springs record unique conditions of their formation and stress that Mofetta Tylicz and similar springs in the Carpathians should be monitored, protected and also used as a touristic sites.

Abstract

The paper characterise the group of $\mathrm{CO}_{2}$-rich (carbonated) water springs in the Carpathians, which are accompanied by exhalation of $\mathrm{CO}_{2}$. These springs called the Mofetta Tylicz are the example of the environmental and touristic unique object. We present geological and hydrogeological background as well as chemical analysis of the springs composition. The springs are characterised by the variability of the chemical composition of analysed groundwater, which indicates the need to implement a systematic monitoring. The monitoring would assess the reasons for this variability and allow the effective protection of spring waters of this area in the future.

\section{Geological settings}

The area of Tylicz, located in Poprad River Valley, is a part of the Polish Carpathians Massif (Beskidy Mts., Beskid Sądecki), a particularly interesting region as a place of therapeutic water drainage (mineral and containing $\mathrm{CO}_{2}$ ) and the groundwater mining area with high touristic potential.

Geologically, this area is located in the south-west part of the Magura Nappe, on the border of the Bystrzyca and the Krynica subunits separated by an inverse fault plunged on NE (Krynica dislocation) (Oszczypko et al., 1999). The Bystrzyca subunit is composed of Łabowa, Beloveža, Żeleźnikowa and Magura formations. This subunit is described as broad zone secondarily pleated syncline (Oszczypko et al., 1999). The Łabowa Formation, with thickness of about $100 \mathrm{~m}$, consists of red shales, thin-bedded flysch with interlocation of red shales. The Beloveža Formation is a complex of 300-m thick sediments, known as turbidites deposits with a predominance of argillaceous sediments. The Żeleźnikowa Formation ( 250 up to $350 \mathrm{~m}$ thick) consists of alternating greybluish calcareous sandstones, marls and marly shales (Oszczypko \& Oszczypko-Clowes, 2010). The Maszkowice Sandstones, the Poprad Sandstones and the Mniszek Shales are components of the Magura Formation. The Maszkowice series represent a fractional layered sandstones (a part of turbidities deposits) that are intercalated with Łącko Marls - dark grey marls (0.5-3.5 m thick). The Mniszek Shales series are composed of variegated shales and thin-bedded flysch. The Poprad Sandstones Member is not mani-
Keywords

carbonated groundwater $\cdot$ therapeutic water $\cdot \mathrm{CO}_{2}$ exhalation $\cdot$ Tylicz $\cdot$ the Carpathians

Received: 10 June 2015 Accepted: 21 October 2015

fested on the surface and is known from deep drillings of several hundred metres depth. Thick-bedded sandstones of this unit mainly consist of medium-grained sands with intercalations of shales and mudstones (Oszczypko et. al., 1999). The Krynica subunit consists of Szczawnica, Zarzecze and Magura formations and has a block fault nature (Oszczypko et al., 1999). The Szczawnica Formation is about $200 \mathrm{~m}$ of thin- to medium-bedded, fine- to medium-grained, calcareous sandstones (flysch). The Zarzecze Formation (which has thickness of up to $650 \mathrm{~m}$ near the estuaries of the Kryniczanka and the Muszynka River) is composed of sandstones, mudstones and grey marble shales. The Magura Formation consists of Piwniczna Sandstones, characterised by the presence of conglomerates, thick-bedded sandstones and mudstones with intercalation of thin-bedded sandstones, mudstones and clay stones (Birkenmajer \& Oszczypko, 1989; Oszczypko \& Oszczypko-Clowes, 2010). In 2010 Oszczypko et al. established a new zone in the area of Tylicz, called Tylicz zone, which is located between the Bystrzyca and Krynica subunits. It contains the same formations as the Bystrzycka subunit.

\section{Hydrogeological conditions}

According to commonly used division by Paczyński (1995), the area of Tylicz is located in the Hydrogeological Carpathian Region (XIV) (Chowaniec, 2006) in the Major Groundwater Basin (MGB) no. 438 - Magura Nappe (Nowy Sącz) - a fissure-pore ba- 


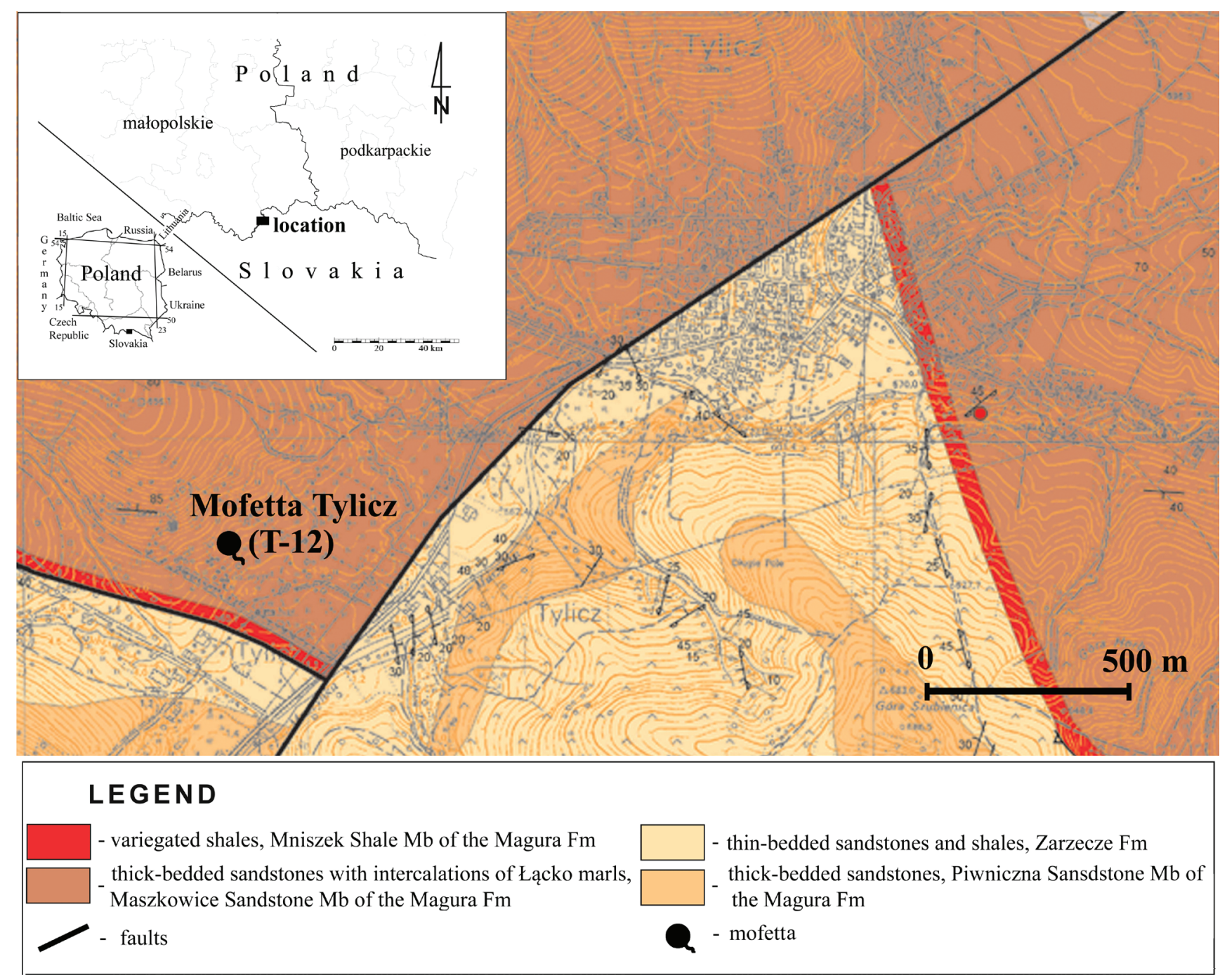

Figure 1. Location of the Mofetta Tylicz on the geological background

sin, with an area of $250 \mathrm{sq} \mathrm{km}$ (Małecka et al., 2007). According to Kleczkowski (1990) and Skrzypczyk (2003), Tylicz is located in the Groundwater Body no. 154 (154 JCWPd). Groundwater of this area occurs in quaternary porous sands and gravels with a thickness of less than $10 \mathrm{~m}$ and Paleogene sandstones with a thickness of 10-20 m (Małecka et al., 2007). The hydraulic conductivity of the pore-fissured sediments ranges from $1.13^{*} 10^{-4}$ to $1.25^{*} 10^{-9} \mathrm{~m} / \mathrm{s}$ (Nałęcki et al., 2004). Long-term investigations of the groundwater runoff in the region of Tylicz (Muszyna catchment) brought varied results, from 0.50 to $13.11 \mathrm{~L} / \mathrm{s}^{*} \mathrm{sq} \mathrm{km}$ (on an average $6.90 \mathrm{~L} / \mathrm{s}^{*} \mathrm{sq} \mathrm{km}$ ), depending on research methods (e.g. Ciężkowski et al., 1999; Guty, 2003; Duńczyk, 2004; Buczyński et al., 2007; Józefko et al., 2013). Significant or a significent form of groundwater drainage in the Tylicz area are springs (mineral, $\mathrm{CO}_{2}-$ rich and fresh groundwater), which were recorded in a number of 365 . Average spring outflow ranges from 0.01 to $0.10 \mathrm{~L} / \mathrm{s}$. The spring density index for the Muszynka River basin is 7.90. The spring runoff, with $2.261 \mathrm{~L} / \mathrm{s}^{*} \mathrm{sq} \mathrm{km}$, is also high (Ciężkowski et al., 1999; Buczyński et al., 2007; Józefko et al., 2013).

The presence of mineral and therapeutical groundwater (226 documented springs) containing $\mathrm{CO}_{2}$ (carbonated water, $\mathrm{CO}_{2}$-rich water) is characteristic for the Carpathians. The Poprad River Valley is famous for the most numerous springs called 'szczawa' with high content of free carbon dioxide (from 320 up to 2996 mg/L in Krynica-Zdrój where this gas is exploited on an industrial scale) (Ciężkowski et al., 2002). Węcławik (1991) proposed a division of mineral waters in the Carpathians into different zones. The central zone, also called zone A, corresponds to fresh carbonated groundwater occurring near the surface. Zone B, known as transition zone, is connected with mineral chloride $\mathrm{CO}_{2}$-rich groundwater. Zone $\mathrm{C}$, for which typical are brines and saline groundwater, occurs in deeper aquifers (Chowaniec, 2009). Chloride mineral and fresh $\mathrm{CO}_{2}$-rich groundwater springs can be both found in the area of Tylicz (Świdzinski, 1972). These springs 


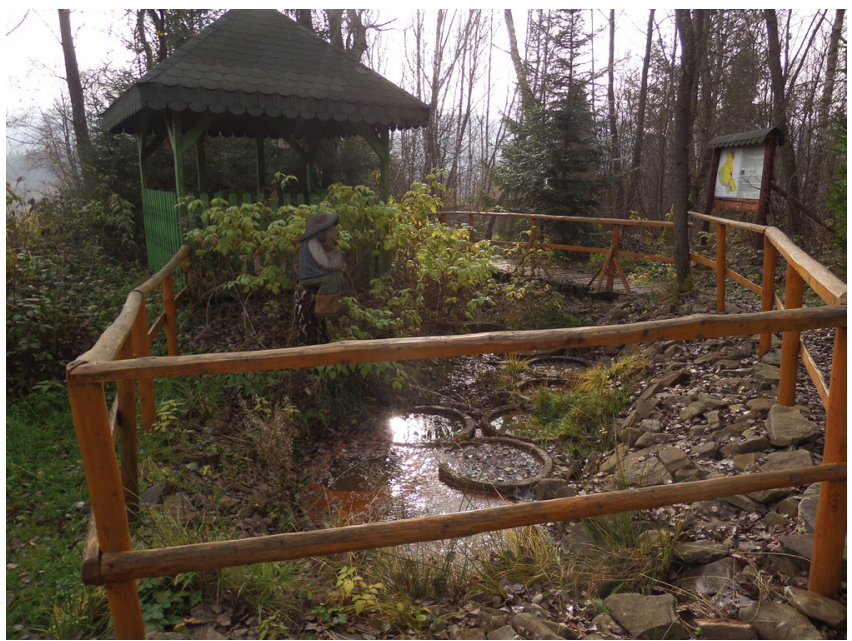

Figure 2. The view of the Mofetta Tylicz

have a great potential to be magnets for tourists as many of them were reconstructed and equipped with information boards and gazebos or benches. Educational nature trails, for example, 'Na Rakowcu' were established as well; however, there are still many springs that are difficult to reach and find.

The origins of the $\mathrm{CO}_{2}$ in the Carpathian formation groundwater is not so easy to define. Results of research varies, what leads to the conclusion that there have to be more than one source of $\mathrm{CO}_{2}$ (Ciężkowski et al., 2002). Lis and Hałas (1980) proved that the origin of $\mathrm{CO}_{2}$ in the area of the Magura Nappe is related to the thermal decay of limestone of Mesozoic and Paleozoic platforms and clastic sediments from Paleogene and lower Miocene (Oszczypko, 1998; Ciężkowski et al., 2002). Studies of Oszczypko and Zuber (2002) suggest that the origin of chloride $\mathrm{CO}_{2}$-rich groundwater is diagenetic as the result of the transition of smectite to illite, which takes place during the diagenesis of flysch sediments. The other metamorphic genesis theory of these water origin (based on the analysis of the isotopic composition) suggests that $\mathrm{CO}_{2}$ arises in the Carpathians from an approximate depth of $15-20 \mathrm{~km}$ as a result of the dehydration and decarbonation of the bottom surface of the Carpathian flysch and base platform formations (Dowgiałło, 1980; Leśniak, 1980; Zuber \& Grabczak, 1985; Zuber, 1987; Ciężkowski et al., 2002). Tectonics of the area seems to play a predominant role in the migration of the gaseous $\mathrm{CO}_{2}$ in the Carpathian flysch (Ciężkowski et al., 2002). According to Ciężkowski et al. (2002), the metamorphic genesis of $\mathrm{CO}_{2}$ cannot be postulated ruthlessly. There is also a possibility for magmatic and biogenetic genesis (Lis and Hałas, 1980; Ciężkowski et al., 2002) requiring precise research especially in the aspect of extraction of $\mathrm{CO}_{2}$ in a bigger scale.

It is worth mentioning that in the Tylicz area, one of the most important regions of exploitation and bottling of therapeutic, mineral and fresh groundwater is located - the mining area TYLICZ I (31.93 sq km) where groundwater exploitation started in

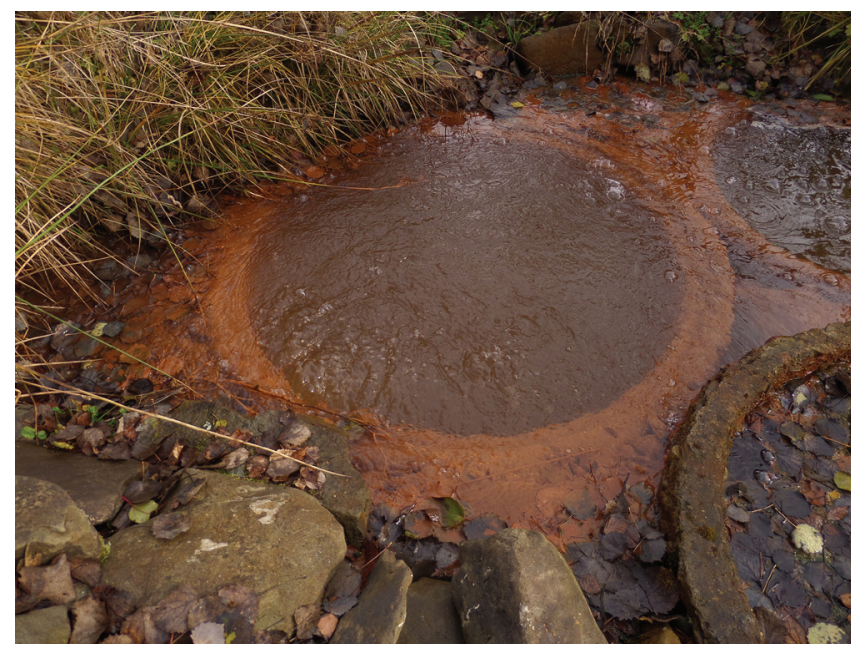

Figure 3. Exhalation of $\mathrm{CO}_{2}$ at the Mofetta Tylicz

the mid 1970s (Ciężkowski \& Kapuściński, 2011; Porwisz et al., 1999; Kucharski \& Sokołowski, 2007). Multivita company has been exploiting in Tylicz and Powroźnik and bottling water of a popular trade names 'Kropla Beskidu' and 'Kropla Minerałów'. Tylicz resources of mineral water are defined for $8.6 \mathrm{~m}^{3} / \mathrm{h}$ with a depression of 11.0-19.5m and are exploited from a depth of 32160 m (Zarzecze Formation, layer of Łącko) (Poprawski et al., 1997; Kucharski \& Sokołowski, 2007).).

\section{Field description of the Mofetta Tylicz}

The Mofetta Tylicz is a group of springs where the exhalation of $\mathrm{CO}_{2}$ and outflow of carbonated water can be observed. Springs are located in the south-west part of the Tylicz village, exact location is to the right bank of the Muszynka River and the slope of the hill Szalone (828.8 $\mathrm{m}$ a.s.I.), between the river valleys Syhowny, from the south and Bradowiec, from the north. It belongs to the territory of the resort 'Domki w lesie' (Houses in the forest). The Mofetta is located at $582 \mathrm{~m}$ a.s.l. and its coordinates are longitude $21^{\circ} 00^{\prime} 72^{\prime \prime}$, latitude $49^{\circ} 39^{\prime} 07^{\prime \prime}$. From geological point of view, it is located in the Bystrzyca subunit near the border with the Krynica subunit in the buffer zone of the Poprad Landscape Park, on the Maszkowice Sandstone Member, which is a part of the Magura Formation (Figure 1).

In the 'Domki w lesie' resort, small signs show the way to the path through the petite forest leading to the springs, which makes it accessible only on foot. Mofetta springs, beleaguered by 11 concrete rings, are situated in low ground, surrounded by a wooden fence. The whole area is cleared of plants. Benches and a gazebo can be used to sit down, relax and watch the bubbling spring. The information board shows the location on a geological map and provids information about the spring like its history and the history of the Tylicz village (Figures 2 and 3). 
Table 1. Main physical and chemical proprieties of the Mofetta Tylicz groundwater - data from 1963 to 2014

\begin{tabular}{c|c|c|c|c|c|c}
\hline Date & $\begin{array}{c}\text { Temperature } \\
{\left[{ }^{\circ} \mathbf{C}\right]}\end{array}$ & $\begin{array}{c}\mathbf{p H} \\
{[-]}\end{array}$ & $\begin{array}{c}\mathbf{E C} \\
{[\mathbf{m S} / \mathbf{c m}]}\end{array}$ & $\begin{array}{c}\mathbf{M}_{\text {tot }} \\
{[\mathbf{m g} / \mathbf{L}]}\end{array}$ & $\begin{array}{c}\text { Free } \mathbf{C O}_{2} \\
{[\mathbf{m g} / \mathbf{L}]}\end{array}$ & Data source \\
\hline 1963 & 12.0 & - & - & - & 940 & cited by Porwisz et al. 1998 \\
\hline 1975 & - & 5.80 & - & 238 & - & cited by Porwisz et al. 1998 \\
\hline $1994-04-20$ & 12.0 & - & - & 861 & 940 & Porwisz et al. 1995 \\
\hline $1994-05-13$ & 11.9 & 4.85 & 0.074 & - & 940 & Porwisz et al. 1995 \\
\hline $1998-06-25$ & 10.0 & - & 0.330 & - & 2292 & Porwisz et al. 1998 \\
\hline $2006-06-01$ & 9.5 & 4.19 & 0.080 & 101.1 & 1100 & Staśko et al. 2007 \\
\hline $2006-09-14$ & 10.4 & 5.28 & 0.445 & 443.5 & 1166 & Staśko et al. 2007 \\
\hline $2014-11-26$ & 8.8 & 5.57 & 0.478 & 250 & 796 & this study
\end{tabular}

Table 2. Chemical composition of the Mofetta Tylicz groundwater - data from 2014

\begin{tabular}{|c|c|c|c|c|c|}
\hline Compound & Unit & Concentration & Compound & Unit & Concentration \\
\hline $\mathrm{HCO}_{3}^{-}$ & \multirow{13}{*}{$\mathrm{mg} / \mathrm{L}$} & 195.3 & $\mathrm{Sr}$ & \multirow{12}{*}{$\mu g / L$} & 609.65 \\
\hline $\mathrm{Cl}^{-}$ & & 2.88 & $\mathrm{Al}$ & & 148.83 \\
\hline $\mathrm{SO}_{4}^{2+}$ & & 1.64 & $\mathrm{Ba}$ & & 51.83 \\
\hline $\mathrm{NO}_{3}^{-}$ & & 0.053 & Li & & 6.42 \\
\hline $\mathrm{NO}_{2}^{-}$ & & 0.025 & $\mathrm{Ni}$ & & 5.23 \\
\hline $\mathrm{HPO}_{4}^{3-}$ & & $<0.01$ & $\mathrm{Cu}$ & & 0.96 \\
\hline $\mathrm{Na}^{+}$ & & 8.51 & $\mathrm{Cd}$ & & 0.21 \\
\hline $\mathrm{K}^{+}$ & & 0.63 & $\mathrm{Zn}$ & & 0.18 \\
\hline $\mathrm{Mg}^{2+}$ & & 3.94 & As & & $<1.0$ \\
\hline $\mathrm{Ca}^{2+}$ & & 31.80 & Co & & $<1.0$ \\
\hline $\mathrm{NH}_{4}^{+}$ & & $<0.01$ & $\mathrm{Cr}$ & & $<1.0$ \\
\hline $\mathrm{Fe}_{\text {tot }}$ & & 3.412 & $\mathrm{~Pb}$ & & $<1.0$ \\
\hline $\mathrm{Mn}$ & & 0.694 & & & \\
\hline
\end{tabular}

\section{Chemical composition of the Mofetta Tylicz springs water}

The Moffeta Tylicz as an important hydrogeological object was a subject of various research particularly in the context of hydrogeological evidence of the Poprad Valley aquifers. Hydrochemical aspects of these studies were limited mainly to determine the basic chemical parameters of groundwater and incomplete chemical analyses (Porwisz et al., 1995; Porwisz et al., 1998; Staśko et al., 2007). Therefore, in November 2014, field works and laboratory analyses were made to allow full characteristic of carbonate groundwater of the Moffeta Tylicz springs.

Electrical conductivity (EC), $\mathrm{pH}$ and temperature were measured in the field, using multiparameter gauge Elmetron CX401. Concentration of free $\mathrm{CO}_{2}$ was measured (also directly in the field) as acidity. A $100 \mathrm{~mL}$ of water sample was titrated with $0.05 \mathrm{M} \mathrm{NaOH}$ in the presence of phenolphthalein. The acidity was converted using the gram-equivalent of free $\mathrm{CO}_{2}$. Concentration of $\mathrm{HCO}_{3}$ was measured as total alkalinity. A $100 \mathrm{~mL}$ of water sample was titrated using $0.05 \mathrm{M} \mathrm{HCl}$ in the presence of methyl orange. The alkalinity, in meq units, was recalculated using the gram-equivalent of $\mathrm{HCO}_{3}{ }^{-}$. Analyses of cations $\left(\mathrm{Na}^{+}, \mathrm{NH}_{4}{ }^{+}, \mathrm{K}^{+}, \mathrm{Mg}^{2+}, \mathrm{Ca}^{2+}\right)$ and anions $\left(\mathrm{Cl}^{-}, \mathrm{NO}_{2}^{-}, \mathrm{NO}_{3}^{-}, \mathrm{SO}_{4}{ }^{2-}, \mathrm{HPO}_{4}{ }^{3-}\right)$ were carried out using Alliance Waters high-performance liquid chromatography (HPLC) 2695 with 432 Conductivity Detector and 2998 Photodiode Array Detector, an IC-Pak Anion HR column (gluconate/borate eluent) and IC-Pak Cation M/D column (EDTA/HNO 3 eluent). Analyses of Fe, Mn, $\mathrm{Sr}$, $\mathrm{Al}, \mathrm{Ba}, \mathrm{Ni}, \mathrm{Li}, \mathrm{Cu}, \mathrm{Cd}, \mathrm{Zn}, \mathrm{As}, \mathrm{Co}, \mathrm{Cr}$ and $\mathrm{Pb}$ were obtained by flame atomic absorption spectrometry (F-AAS) and graphite furnace atomic absorption spectrometry methods (GF-AAS) using GBC Avanta atomic absorption spectrometer.

Actual and previous research showed that groundwater of the Mofetta Tylicz are fresh waters (total mineralisation $<1 \mathrm{~g} / \mathrm{L}$ ) (Table 1) with high content of free $\mathrm{CO}_{2}$ and low $\mathrm{pH}$ value. Temperature of springs ranged from 8.8 to $12.0^{\circ} \mathrm{C}, \mathrm{pH}$ from 4.19 to 5.80 , EC from 0.08 to $0.48 \mathrm{mS} / \mathrm{cm}$ and total mineralisation from 101 to 


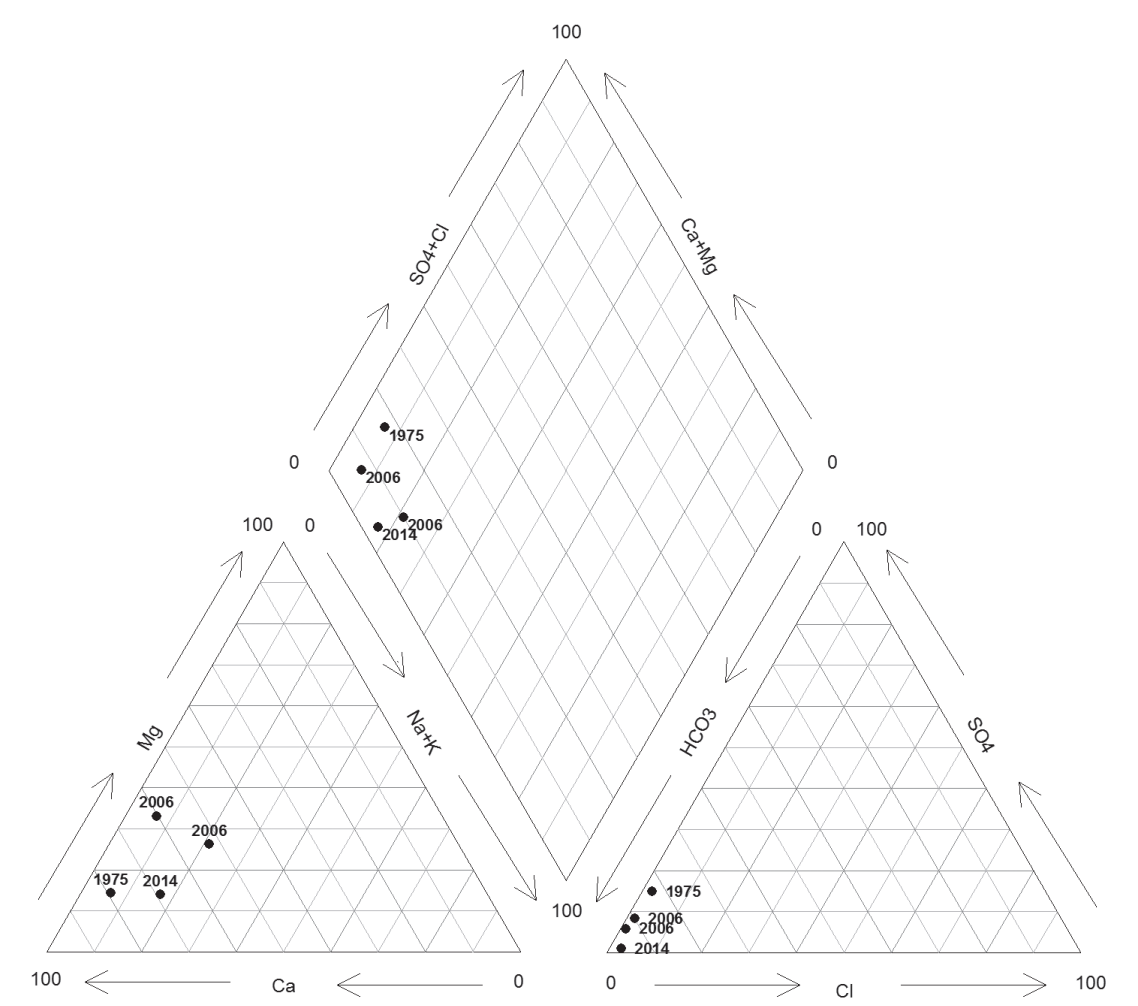

Figure 4. Piper diagram showing groundwater chemistry of the Mofetta Tylicz - data from 1975, 2006, 2014

$\mathrm{CO}_{2}^{0,8-2,29} \mathrm{M}^{0,10-0,86} \frac{\mathrm{HCO}_{3}^{83-97} \mathrm{SO}_{4}^{1-15} \mathrm{Cl}^{1-2}}{\mathrm{Ca}^{52-79} \mathrm{Mg}^{14-33} \mathrm{Na}^{6-17} \mathrm{~K}^{1-5}} \mathrm{~T}^{9-12}$

Figure 5. Kurlov's formula for data from 1963 to 2014; $\mathrm{CO}_{2}$ in $\mathrm{g} / \mathrm{L}, \mathrm{M}$ in $\mathrm{g} / \mathrm{L}$, anions and cations in $\% \mathrm{meq} / \mathrm{L}, \mathrm{T}$ in ${ }^{\circ} \mathrm{C}$.

$861 \mathrm{mg} / \mathrm{L}$. The amount of free $\mathrm{CO}_{2}$ ranged from 796 to $2292 \mathrm{mg} / \mathrm{L}$ (Table 1). All main chemical properties of water showed significant changes over the time, even during one year (2006) but still remained in a specified range (Figures 4 and 5; Table 1). At the same time, changes in chemical composition of main ions over the time were also observed. The groundwater studied in 2014 represented hydrogeochemical type $\mathrm{HCO}_{3}-\mathrm{Ca}$; however, earlier studies showed the water type $\mathrm{HCO}_{3}-\mathrm{Ca}-\mathrm{Mg}$ (2006) (Figures 4 and 5). This phenomena is typical for shallow $\mathrm{CO}_{2}$-rich groundwater of Carpathian zone A where shallow flow systems are highly sensitive to recharge and outflow changes, water mixing processes and anthropogenic influence. These processes often cause a change in hydrogeological and hydrogeochemical regime (Węcławik, 1991; Ciężkowski \& Kapuściński, 2011; Rajchel, 2012). On the other hand, very low concentration of $\mathrm{NO}_{3}{ }^{-}, \mathrm{NO}_{2}{ }^{-}$, $\mathrm{HPO}_{4}{ }^{3-}$ and $\mathrm{NH}_{4}^{+}$ions noted in water studied in 2014 (Table 2) suggest that the Mofetta Tylicz springs were not exposed to the direct influence of anthropogenic pollution (e.g. fertilization and sludge) (Witczak et al., 2013). Concentrations of almost all main ions and metals analyzed in 2014 were below the Polish standards for water intended for human consumption (MH, 2010) and showed a good chemical status of groundwater (class I to III), according to the Regulation of the Minister of Environment (RME, 2008) (Table 2). Only iron (3.412 mg/L) and manganese $(0.694 \mathrm{mg} / \mathrm{L})$ concentrations were probably higher as a result of natural processes accompanying chemical reactions associated with the presence of acidic $\mathrm{CO}_{2}$ in a flow system (Witczak et al., 2013).

\section{Conclusion}

The Carpathians, particularly the area of Tylicz, are well known for their therapeutic springs. Their specific properties (mineralisation, amount of free $\mathrm{CO}_{2}$ ) make these waters ideal for geological field trips. A particular attention should be paid to springs with high free $\mathrm{CO}_{2}$ content and $\mathrm{CO}_{2}$ exhalation such as the Mofetta Tylicz. These studies showed that groundwater of the Mofetta Tylicz springs do not have a stable chemical composition and should be a subject of systematic chemical monitoring to indicate the reasons of the long-term groundwater's change over time. Also from the touristic point of view, many springs in the Tylicz area are not accessible or adopted for touristic visits and, therefore, are still not fully used. These unique natural wonders should be made available for visitors and tourists. 


\section{Acknowledgements}

This work was financially supported by Multivita, University's Council of Student Scientific Clubs and Department of General
Hydrogeology (1017/S/ING/14) in the University of Wrocław. The authors wish to express their gratitude to the staff of Multivita and to Dr Marta Jakubiak and Dr Marek Wcisło for their help in fieldwork.

\section{References}

[1] Birkenmajer K., Oszczypko N. 1989. Cretaceous and Palaeogene lithostratigraphic units of the Magura Nappe, Krynica Subunit, Carpathians. (in English with Polish summary). Ann. Soc. Geo. Pol., 59: 145-181.

[2] Buczyński S., Olichwer T., Tarka R., Staśko S. 2007.Water bearing of Carpathian flysch formation base on springs research in Krynicki Beskid - Tylicz region in. Contemporary problems of hydrogeology (in Polish with English summary). WGGiOOE AGH, Kraków, 13, 2: 403-411.

[3] Chowaniec J. 2006. Carpathian Hydrogeology (in Polish). Pol. Geol. Rev., 54, 10: 846-847.

[4] Chowaniec J. 2009. Hydrogeology study of the western part of the Polish Carpathians. Biul. Państw. Inst. Geol., 434: 1-98.

[5] Chowaniec J., Zuber A., Ciężkowski W. 2007. Carpathian Province. [In:] Paczyński B., Sadurski A. (eds.) Regional Hydrogeology of Poland. V. II, Mineral Waters (in Polish), 88-96, Państwowy Instytut Geologiczny, Warsaw.

[6] Ciężkowski W., Duliński W., Józefko I., Kiełczawa B., Liber-Madziarz E., Witczak S., Zuber A., Żak S. 2002. Occurrence, documentation and exploitation of endogenous carbon dioxide in Poland (in Polish). Wrocławskie Towarzystwo Naukowe. Warsaw.

[7] Ciężkowski W., Józefko I., Kiełczawa B., Krawiec A., Elżbieta Liber., Nowicki Z., Przylibski T., Sadurski A., Skrzypczyk L., Sokołowski A. 2007. Interaction of mineral and medical waters - rules of documentation, protection and water management (in Polish). Oficyna Wydawnicza Politechniki Wrocławskie. Wrocław.

[8] Ciężkowski W., Kapuściński J. 2011 Determination of the Borders of Mining Area and Mining Terrain for the Occurrence of Groundwater Acclaimed as Minerals. [in:] Procedure Guidebook (in Polish), 82-83, Ministerstwo Środowiska, Warsaw.

[9] Ciężkowski W., Kozłowski J., Liber-Madziarz E., Przylibski T.A., Żak S. 1999. Specific groundwater runoff diversification in Kryniczanka river basin during groundwater flow period (in Polish with English summary). Pol. Geol. Rev., 47, 6: 564-566.

[10] Dowgiałło J. 1980. Polygenetic model of Carpathian chloride waters and some of its consequences. Contemporary issues of regional hydrogeology. Jachranka 12- 14.12.1980, 275-290, Uniwersytet Warszawski, Warsaw.

[11] Duńczyk L. 2004. Underground runoff modeling for selected catchment area in Sudeten Beskid and Gorcow (in Polish). [PhD thesis]. Arch. ING UJ, Kraków.

[12] Gutył. 2003. Renewable groundwater resources from a selected area from the stream Złockie catchment area (in Polish). [Master thesis]. Arch. WGGiOŚ AGH, Kraków.

[13] Józefko I., Oszczypko N., Kukuła M. 2013. Assessment of waterbearing capacity of flysch deposits in the Muszyna region based on spring investigation (in Polish with English summary). Biul. Państw. Inst. Geol., 456: 233-242.

[14] Kleczkowski A.S. 1990. The Map of the Critical Protection Areas (CPA) of the Major Groundwater Basins (MGWB) in Poland (in Polish). 1: 500000 Wyd. AG, Kraków.

[15] Kucharski M., Sokołowski J. 2007. The Use of Medical Waters in Bottling Process. [in:] (eds.) Regional Hydrogeology of Poland. V. II, Min- eral Waters (in Polish), 103-119, Państwowy Instytut Geologiczny, Warsaw.

[16] Leśniak P. 1980. The Origin of chloride waters at Wysowa, West Carpathians. Chemical and isotopic approach (in English with Polish summary). Acta. Geol. Pol., 30, 4: 519-550.

[17] Lis J., Hałas S. 1980. Preliminary results of stable carbon isotope studies in Sudetic and Carpathian mineral waters. ZFI-Mitt., 29: 69-82.

[18] Małecka D., Chowaniec J., Małecki J.J. 2007. Upper Wisła Region. [in:] (eds.) Regional Hydrogeology of Poland. V. I, Fresh waters (in Polish), 108-159, Państwowy Instytut Geoloogiczny, Warsaw.

[19] Nałęcki P., Reśko D., Schmalz A., Witczak S. 2004. Hydrogeological parameter description of fissured-porous therapeutic groundwater basin in Krynica. Biul. Państw. Inst. Geol., 404: 144-164.

[20] Oszczypko N. 1998. The Western Carpathian Foredeep - development of the foreland basin in front of the accretionary wedge and its burial history (Poland). Geol. Carpath., 49, 6: 415-431.

[21] Oszczypko N., Malata E., Oszczypko-Clowes M., Duńczyk L. 1999. Geology of the Krynica area (Maggura Nappe, Polish Outer Carpathians) (in Polish with English summary). Pol. Geol. Rev., 47: 549-559.

[22] Oszczypko N., Oszczypko-Clowes M. 2010. The Paleogene and nearly Neogene stratigraphy of the Beskid Sądecki Range and Lubovnianska Vrchovina Magura Nappe Western Outer Carpathians. Acta. Geol. Pol., 60, 3: 317-348.

[23] Oszczypko N., Zuber A. 2002. Diagenetic component in mineral waters of the Polish Outer Carpathians: A Krynica Spa case study. Geol. Carpath., 53: 257-268.

[24] Paczyński B. 1995. Polish hydrogeological atlas 1: 500 000, Vol. II, resources, quality and protection of fresh water (in Polish). Państwowy Instytut Geologiczny, Warsaw.

[25] Poprawski L., Biniak G., Gurwin J., Jasiak T., Kowalczyk A., Krzempek J., Kus S., Limisiewicz P., Marszałek H., Napierała K., Olszewski W., Wąsik M., Cisek J. 1997. Documentation of available resources and exploitation of groundwater (fresh and therapeutic) in the spa in Krynica, Muszynka and Piwniczna (in Polish). PPUH 'HYDROGEO' Ltd., Wrocław.

[26] Porwisz B., Radwan J., Zuber A. 1999. Groundwater recharge in the Tylicz region In: Current problems of hydrogeology (in Polish with English summary). Państw. Inst. Geol., 9: 287-292.

[27] Porwisz B., Radwan J., Zuber A., Kowalski J., Mądry J., Cisek J. 1998. Hydrogeological documentation of groundwater exploitation resources in tertiary layers for the ZPWM 'Multico' in Tylicz (in Polish). Przedsiębiorstwo Naukowo-Techniczne "OMEGA", Kraków.

[28] Porwisz B., Radwan J., Zuber A., Węcławik S., Cisek J., Kowalski J., Mądry J. 1995. Definition of feeding areas of Groundwater deposits (fresh, mineral and therapeutic) exploited through wells by the Mineral Water Production Plant "Multico" (in Polish). Archiwum PG, Kraków.

[29] Rajchel L. 2012. Carbonated waters and waters containing carbon dioxide of the Polish Carpathians (in Polish). Wydawnictwa AGH, Kraków.

[30] Regulation of the Minister of Environmental. 23 July 2008. Amending on the criteria and method of evaluation of groundwater (in Polish). J. Law., 143: 896.Regulation of the Minister of Health. 20 April 2010. Amending regulation on the quality of water intended for human 
consumption (in Polish). J. Law., 72: 466.Skrzypczyk L. 2003. Map of Major Groundwater Reservoirs .1: 50 0000. Państwowy Instytut Geologiczny, Warsaw.

[31] Staśko, S., Ciężkowski, W., Oszczypko N., Modelska M., Buczyński S., Olichwer T., Tarka R., Wcisło M. 2007. Hydrogeological documentation to determination of fresh and mineral groundwater resources for the upper drainage basin of the river Muszynka (in Polish). Uniwersytet Wrocławski, Wrocław.

[32] Świdziński H. 1972. Geology and mineral waters of Krynica (in Polish). Wydawnictwo Geologiczne, Warszawa.
[33] Węcławik S. 1991. Complex research methodology to guard balneological raw materials from the effects of industry (in Polish). CPPGSMiE PAN, Kraków, Studies and trakt, 11.

[34] Witczak S., Kania J., Kmiecik E. 2013. Catalogue of selected physical and chemical indicators of pollution of groundwater and methods of their determination (in Polish). Inspekcja Ochrony Środowiska, Warsaw.

[35] Zuber A. 1987. The origin of water types called Zuber. 25 years of therapeutical water mining. Krynica. Ed. AGH Kraków: 337-351.

[36] Zuber A., Grabczak J. 1985. The origin of some of the southern Polish mineral waters shown through isotope studies. Current problems of hydrogeology. Ed. AGH, Kraków: 37-51. 